\title{
Front Matter: Volume 9978
}

, "Front Matter: Volume 9978," Proc. SPIE 9978, CubeSats and NanoSats for Remote Sensing, 997801 (7 November 2016); doi: 10.1117/12.2260739

SPIE Event: SPIE Optical Engineering + Applications, 2016, San Diego, California, SPIE. United States 


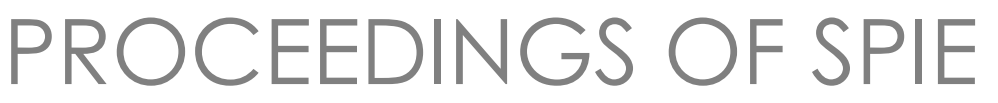

\section{CubeSats and NanoSats for Remote Sensing}

Thomas S. Pagano

Editor

31 August 2016

San Diego, California, United States

Sponsored and Published by

SPIE 
The papers in this volume were part of the technical conference cited on the cover and title page. Papers were selected and subject to review by the editors and conference program committee. Some conference presentations may not be available for publication. Additional papers and presentation recordings may be available online in the SPIE Digital Library at SPIEDigitallibrary.org.

The papers reflect the work and thoughts of the authors and are published herein as submitted. The publisher is not responsible for the validity of the information or for any outcomes resulting from reliance thereon.

Please use the following format to cite material from these proceedings:

Author(s), "Title of Paper," in CubeSats and NanoSats for Remote Sensing, edited by Thomas S. Pagano, Proceedings of SPIE Vol. 9978 (SPIE, Bellingham, WA, 2016) Six-Digit Article CID Number.

ISSN: 0277-786X

ISSN: 1996-756X (electronic)

ISBN: 9781510603479

ISBN: 9781510603486 (electronic)

Published by

SPIE

P.O. Box 10, Bellingham, Washington 98227-0010 USA

Telephone +1 3606763290 (Pacific Time) · Fax +1 3606471445

SPIE.org

Copyright (C) 2016, Society of Photo-Optical Instrumentation Engineers.

Copying of material in this book for internal or personal use, or for the internal or personal use of specific clients, beyond the fair use provisions granted by the U.S. Copyright Law is authorized by SPIE subject to payment of copying fees. The Transactional Reporting Service base fee for this volume is $\$ 18.00$ per article (or portion thereof), which should be paid directly to the Copyright Clearance Center (CCC), 222 Rosewood Drive, Danvers, MA 01923. Payment may also be made electronically through CCC Online at copyright.com. Other copying for republication, resale, advertising or promotion, or any form of systematic or multiple reproduction of any material in this book is prohibited except with permission in writing from the publisher. The CCC fee code is 0277-786X/16/\$18.00.

Printed in the United States of America.

Publication of record for individual papers is online in the SPIE Digital Library.

\section{SPIE. DIGITAL}

Paper Numbering: Proceedings of SPIE follow an e-First publication model. A unique citation identifier (CID) number is assigned to each article at the time of publication. Utilization of CIDs allows articles to be fully citable as soon as they are published online, and connects the same identifier to all online and print versions of the publication. SPIE uses a six-digit CID article numbering system structured as follows:

- The first four digits correspond to the SPIE volume number.

- The last two digits indicate publication order within the volume using a Base 36 numbering system employing both numerals and letters. These two-number sets start with 00, 01, 02, 03, 04 , 05, 06, 07, 08, 09, OA, OB ... 0Z, followed by 10-1Z, 20-2Z, etc. The CID Number appears on each page of the manuscript. 


\title{
Contents
}

\author{
$\checkmark$ Authors \\ vii Conference Committee
}

\section{ATMOSPHERE AND WEATHER}

997804 MISTiC Winds: A micro-satellite constellation approach to high resolution observations of the atmosphere using infrared sounding and 3D winds measurements [9978-3]

997805 HyperCube: a hyperspectral CubeSat constellation for measurements of 3D winds [9978-4]

997806 Measurement approach and design of the CubeSat Infrared Atmospheric Sounder (CIRAS) [9978-5]

997809 Design and demonstration of a CubeSat-scale spatial heterodyne imaging spectrometer [9978-8]

9978 OA CICERO: nanosat arrays for continuous Earth remote observation [9978-9]

SOLAR AND PLANETARY EXPLORATION

9978 OD Terrestrial gamma-ray flashes monitor demonstrator on CubeSat [9978-12]

OCEAN AND LAND

9978 OE CIRiS: Compact Infrared Radiometer in Space [9978-13]

$9978 \mathrm{OH} \quad$ HawkEye: CubeSat SeaWiFS update [9978-16]

ENABLING TECHNOLOGIES

9978 OL Fast cool-down coaxial pulse tube microcooler [9978-20]

POSTER SESSION

9978 ON VZLUSAT-1: verification of new materials and technologies for space [9978-23] 
Proc. of SPIE Vol. $9978997801-4$

Downloaded From: https://www.spiedigitallibrary.org/conference-proceedings-of-spie on 26 Apr 2023 Terms of Use: https://www.spiedigitallibrary.org/terms-of-use 


\section{Authors}

Numbers in the index correspond to the last two digits of the six-digit citation identifier (CID) article numbering system used in Proceedings of SPIE. The first four digits reflect the volume number. Base 36 numbering is employed for the last two digits and indicates the order of articles within the volume. Numbers start with 00, 01, 02, 03, 04, 05, 06, 07, 08, 09, OA, OB...0Z, followed by 10-1Z, 20-2Z, etc.

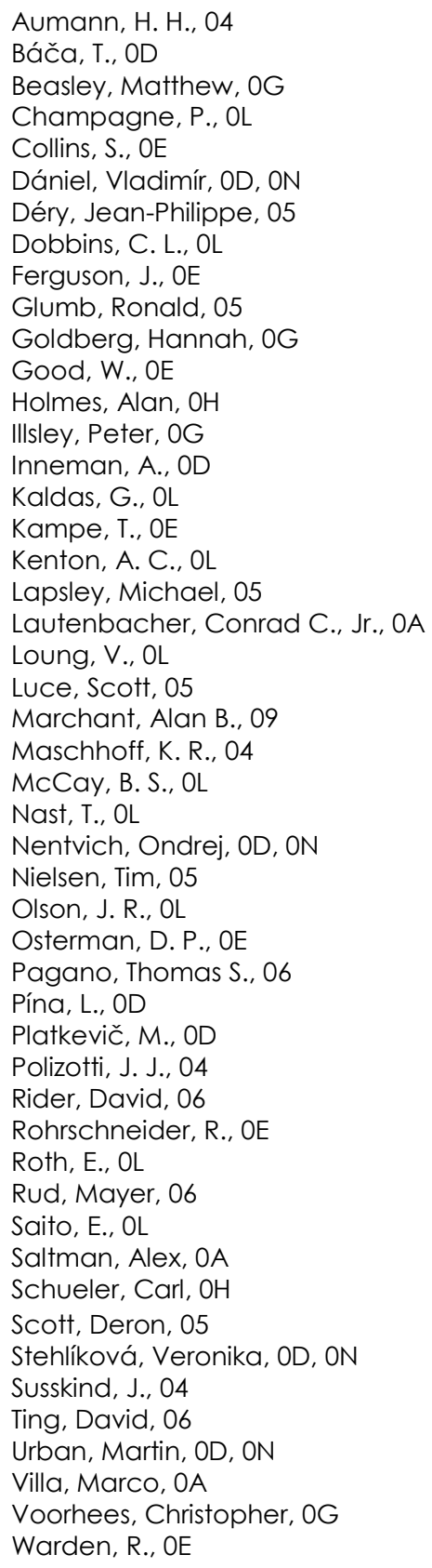

Williams, Austin, OA

Yee, Karl, 06

Yunck, Thomas P., OA

Zadražil, V., OD 
Proc. of SPIE Vol. $9978997801-6$

Downloaded From: https://www.spiedigitallibrary.org/conference-proceedings-of-spie on 26 Apr 2023 Terms of Use: https://www.spiedigitallibrary.org/terms-of-use 


\section{Conference Committee}

Program Track Chair

Allen H.-L. Huang, University of Wisconsin-Madison (United States)

Conference Chair

Thomas S. Pagano, Jet Propulsion Laboratory (United States)

Conference Co-chair

Charles D. Norton, Jet Propulsion Laboratory, California Institute of Technology (United States)

Conference Program Committee

William J. Blackwell, MIT Lincoln Laboratory (United States) Siegfried W. Janson, The Aerospace Corporation (United States)

Clarence M. Korendyke, U.S. Naval Research Laboratory (United States)

Pamela Millar, NASA Goddard Space Flight Center (United States)

Pantazis Mouroulis, Jet Propulsion Laboratory (United States)

Jeffery J. Puschell, Raytheon Space and Airborne Systems (United States)

Michael S. Seablom, NASA Headquarters (United States)

Charles M. Swenson, Utah State University (United States)

Thomas H. Zurbuchen, University of Michigan (United States)

Session Chairs

1 Opening Session

Thomas S. Pagano, Jet Propulsion Laboratory (United States)

Charles D. Norton, Jet Propulsion Laboratory, California Institute of Technology (United States)

2 Atmosphere and Weather

William J. Blackwell, MIT Lincoln Laboratory (United States)

Michael S. Seablom, NASA Headquarters (United States)

3 Solar and Planetary Exploration

Thomas H. Zurbuchen, University of Michigan (United States)

Siegfried W. Janson, The Aerospace Corporation (United States) 
$4 \quad$ Ocean and Land

Jeffery J. Puschell, Raytheon Space and Airborne Systems

(United States)

Clarence M. Korendyke, U.S. Naval Research Laboratory

(United States)

$5 \quad$ Enabling Technologies

Charles D. Norton, Jet Propulsion Laboratory, California Institute of Technology (United States)

Charles M. Swenson, Utah State University (United States)

6 Closing Session

Thomas S. Pagano, Jet Propulsion Laboratory (United States)

Charles D. Norton, Jet Propulsion Laboratory, California Institute of Technology (United States) 